\title{
Is Microarray Analysis Really Useful and Sufficient to Diagnose Nut Allergy in the Mediterranean Area?
}

Goikoetxea $\mathrm{MJ}^{* 1}$, D'Amelio $\mathrm{CM}^{* 1}$, Martínez-Aranguren R', Gamboa P2, Garcia $\mathrm{BE}^{3}$, Gómez $\mathrm{F}^{4}$, Fernández $\mathrm{J}^{5}$, Bartra $\mathrm{J}^{6}$, Parra $\mathrm{A}^{7}$, Alvarado $\mathrm{Ml}^{8}$, Alonso $\mathrm{Ml}^{9}$, González $\mathrm{E}^{10}$, Terrados $\mathrm{S}^{11}$, Moya $\mathrm{C}^{12}$, Blanca-López $\mathrm{N}^{13}$, Feo-Brito $\mathrm{F}^{14}$, Villalba $\mathrm{M}^{15}$, Díaz-Perales $\mathrm{A}^{16}$, Sanz $\mathrm{ML}^{1}$

'Department of Allergy and Clinical Immunology, Clinica Universidad de Navarra, Instituto de Investigación Sanitaria de Navarra, Pamplona, Spain

${ }^{2}$ Allergy Department, Hospital de Basurto, Bilbao, Spain

${ }^{3}$ Allergy Department, Complejo Hospitalario de Navarra, Instituto de Investigación Sanitaria de Navarra, Pamplona, Spain

${ }^{4}$ Allergy Department, Hospital Regional Universitario de Málaga, IBIMA, Málaga, Spain

${ }^{5}$ Allergy Department, Hospital General Universitario de Alicante, Alicante, Spain

${ }^{6}$ Allergy, Respiratory, and Respiratory Allergy Department, Hospital Clinic, Universitat de Barcelona, Institut d'Investigacions Biomédiques August Pi i Sunyer (IDIBAPS), Centro de Investigaciones Biomédicas en Red de Enfermedades Respiratorias (CIBERES)

${ }^{7}$ Allergy Department, Hospital de A Coruña, A Coruña, Spain

${ }^{8}$ Allergy Department, Hospital Virgen del Puerto, Plasencia, Cáceres, Spain

${ }^{9}$ Allergy Department, Hospital de Alcorcón, Madrid, Spain

${ }^{10}$ Allergy Department, Hospital de Fuenlabrada, Madrid, Spain

${ }^{11}$ Allergy Department, Hospital Ramón y Cajal, Madrid, Spain

${ }^{12}$ Allergy Department, Complejo Hopitalario Torrecárdenas, Almeria, Spain

${ }^{13}$ Allergy Department, Hospital Infanta Leonor, Madrid, Spain

${ }^{14}$ Allergy Department, Hospital General Universitario de Ciudad Real, Ciudad Real, Spain

${ }^{15}$ Molecular Biology Department, Facultad de Químicas, Universidad Complutense, Madrid, Spain

${ }^{16}$ Biotechnology Department, Centro de Biotecnología y Genómica de Plantas, Pozuelo de Alarcón, Madrid, Spain

*Both authors contributed equally to this work.

J Investig Allergol Clin Immunol 2016; Vol. 26(1): 31-39

doi: 10.18176/jiaci.0005 


\section{Abstract}

Background: Component-based diagnosis on multiplex platforms is widely used in food allergy but its clinical performance has not been evaluated in nut allergy.

Objective: To assess the diagnostic performance of a commercial protein microarray in the determination of specific $\lg \mathrm{E}(\mathrm{s} \lg \mathrm{E}$ ) in peanut, hazelnut, and walnut allergy.

Methods: slgE was measured in 36 peanut-allergic, 36 hazelnut-allergic, and 44 walnut-allergic patients by ISAC 112, and subsequently, slgE against available components was determined by ImmunoCAP in patients with negative ISAC results. ImmunoCAP was also used to measure slgE to Ara h 9, Cor a 8, and Jugr 3 in a subgroup of lipid transfer protein (LTP)-sensitized nut-allergic patients (positive skin prick test to LTP-enriched extract). slgE levels by ImmunoCAP were compared with ISAC ranges.

Results: Most peanut-, hazelnut-, and walnut-allergic patients were sensitized to the corresponding nut LTP (Ara h 9, 66.7\%; Cor a 8, 80.5\%; Jug r 3, 84\% respectively). However, ISAC did not detect slgE in 33.3\% of peanut-allergic patients, $13.9 \%$ of hazelnut-allergic patients, or 13.6\% of walnut-allergic patients. slgE determination by ImmunoCAP detected sensitization to Ara h 9, Cor a 8, and Jug r 3 in, respectively, $61.5 \%$ of peanut-allergic patients, $60 \%$ of hazelnut-allergic patients, and $88.3 \%$ of walnut-allergic patients with negative ISAC results. In the subgroup of peach LTP-sensitized patients, Ara h 9 slgE was detected in more cases by ImmunoCAP than by ISAC $(94.4 \%$ vs $72.2 \%, P<.05)$. Similar rates of Cor a 8 and Jug $r 3$ sensitization were detected by both techniques.

Conclusions: The diagnostic performance of ISAC was adequate for hazelnut and walnut allergy but not for peanut allergy. slgE sensitivity against Arah 9 in ISAC needs to be improved.

Key words: Hazelnut. Lipid transfer protein. Microarray. Peanut. Walnut.

\section{Resumen}

Introducción: La utilidad clínica del diagnóstico por componentes no ha sido evaluada en el estudio de la alergia a frutos secos (FS). Objetivo: Evaluar la capacidad diagnóstica de una micromatriz comercial de proteínas alergénicas en la alergia a cacahuete, avellana y nuez. Métodos: Se determinó la slgE en pacientes alérgicos a FS mediante la micromatriz ISAC 112, e ImmunoCAP en los pacientes con slgE negativa frente a los componentes de ISAC. Además, se realizó ImmunoCAP frente a Ara h 9, Cor a 8 y Jug r 3 en un subgrupo de pacientes sensibilizados a LTP. La slgE detectada por ImmunoCAP fue comparada con los rangos de ISAC.

Resultados: La mayoría de los alérgicos a cacahuete $(66,7 \%)$, avellana $(80,5 \%)$ y nuez $(84 \%)$ estaba sensibilizados a su LTP. Sin embargo, no se detectó slgE frente a los componentes de ISAC en el 33,3\% de alérgicos a cacahuete, 13,9\% de alérgicos a avellana y 13,6\% de los alérgicos a nuez. El ImmunoCAP permitió detectar slgE a Ara h 9 en 61,5\%, Cor a 8 en $60 \%$ y Jug r 3 en $83,3 \%$ de los ISAC negativo. En el subgrupo LTP, ImmunoCAP $(94,4 \%)$ fue superior a ISAC $(72,2 \%)$ en la detección de slgE a Ara h $9(p<0,05)$. La slgE frente a Cor a 8 y Jug 3 fue detectada de forma similar por ambas técnicas.

Conclusiones: La micromatriz ISAC es adecuada para el diagnóstico de alergia a avellana y nuez. La sensibilidad del componente Arah 9 de ISAC debe ser mejorada.

Palabras clave: Avellana. LTP. Micromatriz. Cacahuete. Nuez.

\section{Introduction}

Tree nuts are considered to be one of the most allergenic plant foods [1] and are an important cause of anaphylaxis [2]. Peanuts are a member of the Leguminosae family, and grow underground, unlike other nuts such as walnuts. They are, however, widely consumed and frequently found together with other tree nuts such as hazelnuts and walnuts. For practical purposes, peanuts will be considered tree nuts for the purpose of this study.

The use of component-resolved diagnosis (CRD) has improved the diagnosis of food allergies, as different allergenic profiles have been reported to be related to particular types of clinical reactivity [3-5]. Furthermore, differences in allergenic profiles have been described for different geographical regions [6,7]. Lipid transfer proteins (LTPs) are the main allergens in tree nut allergy in the Mediterranean area $[6,8,9]$, although it has been suggested that LTPs might also be markers of peach sensitization in the absence of clinical allergy $[8,10]$. In this scenario, multiplex platforms for the quantitative determination of specific $\operatorname{IgE}(\mathrm{sIgE})$ are useful, since $\operatorname{sgE}$ against LTPs and other nut components can be measured in a single test.

It is accepted that $\mathrm{CRD}$, through protein microarrays, offers the possibility of analyzing sIgE against multiple allergens, bringing the allergist closer to more individualized diagnoses and thus allowing a more tailored approach to allergy treatment and management [11]. However, despite the widespread use of CRD in clinical practice, few studies have analyzed the clinical utility of the commercially available microarray platformImmunoCAP ISAC CRD112 - in nut allergy [12-14], and low specificity has been identified for certain nut components such as Jug r 2 [15].

The objective of this study was to evaluate the diagnostic performance of ImmunoCAP ISAC CRD112 (ISAC) (Thermo Fisher Scientific) in the detection of $\operatorname{sgE}$ against peanut, hazelnut, and walnut allergen components in a Mediterranean area. We also sought to evaluate whether measurement of molecular components not included in ISAC might improve the diagnosis of nut allergy in our area. 


\section{Material and Methods}

\section{Patients}

We enrolled 39 peanut-allergic, 36 hazelnut-allergic, and 44 walnut-allergic nonpediatric patients (aged $\geq 14$ years) with clear IgE-mediated allergic symptoms, a positive skin prick test (SPT), and positive sIgE determination $\left(\geq 0.35 \mathrm{kU}_{\mathrm{A}} / \mathrm{L}\right.$ ImmunoCAP, Thermo Fisher Scientific) to the tree nut(s) triggering their allergic reaction. A detailed clinical history and a complete questionnaire were obtained from each patient regarding demographic characteristics, atopic history, and food habits. Symptoms were categorized into oral allergy syndrome, systemic symptoms, and anaphylaxis. When patients experienced more than 2 types of reactions with the same nut, the reaction associated with the severest symptoms was recorded as the most serious reaction. Eighty-one controls (37 with rhinitis and/or bronchial asthma and sensitized to dust mites but not to plant foods or pollen and 44 nonatopic controls) were also enrolled. Enrolment was performed in 14 hospitals across Spain. The study was approved by the ethics committee of Clinica Universidad de Navarra (045/2011) and this approval was supported by the ethics committees at the rest of participating hospitals.

\section{Skin Prick Tests}

SPTs were performed in all participants with commercial extracts of peanut, hazelnut, walnut, and peach $(30 \mu \mathrm{g} / \mathrm{mL}$ of Prup 3) (ALK Abelló). Sodium chloride (0.9\%) and histamine hydrochloride $(10 \mathrm{mg} / \mathrm{mL}$, ALK-Abelló) served as negative and positive controls, respectively. Wheals of $3 \mathrm{~mm}$ in diameter were considered positive, as recommended by the European Academy of Allergy Clinical Immunology guidelines [16].

\section{Multiplex Specific IgE}

Specific IgE against rAra h 1, rAra h 2, rAra h 3, rAra h 8, rAra h 9, rCor a 1.0410 (from now on referred as Cor a 1), rCora 8, nCora 9, rJugr 1, nJugr 2, nJugr 3, and rPrup 3, among other components, was measured using ISAC in accordance with the manufacturer's instructions. Specific IgE values were expressed in ISAC standard units (ISU), with values of 0.3 ISU or greater considered positive. As the technique is semiquantitative, ISU values were grouped into established ranges $(<0.3$ ISU, not detectable; $\geq 0.3$ to $<1$ ISU, low; $\geq 1$ to $<15$, moderate; and $\geq 15$, very high) following the manufacturer's instructions.

In nut-allergic patients with a negative result to the corresponding nut components in ISAC, sensitization to panallergens and other allergen families (LTPs, profilins, PR10 proteins, $2 \mathrm{~s}$ albumin, $11 \mathrm{~s}$ globulin, and 7s globulin) was also analyzed in ISAC.

\section{Single Specific IgE Against Nut Components}

In allergic patients with negative results to nut components in ISAC, sIgE against rAra h 1, rAra h 2, rAra h 3, rAra h 8, rAra h 9, rCor a 1, rCor a 8, nCor a 9, rCor a 14, Jug r 1, and rJug $\mathrm{r} 3$ was measured by fluorescence enzyme immunoassay (ImmunoCAP, Thermo Fisher Scientific) following the manufacturer's instructions. Moreover, in peanut-, hazelnut-, and walnut-allergic patients with a positive SPT to Pru p 3 enriched peach extract, sIgE against Arah 9 (peanut), Cor a 8 (hazelnut), and Jugr 3 (walnut) was measured. Specific IgE against Ara h 9, Cor a 8, and Jug r 3 was also determined by ImmunoCAP in 30 randomly selected controls (15 atopic and 15 nonatopic). Specific $\operatorname{IgE}$ values were quantified in $\mathrm{kUA} / \mathrm{L}$, and values of $0.35 \mathrm{kU}_{\mathrm{A}} / \mathrm{L}$ and greater were considered positive.

Specific IgE against nAra h 6 (ETSIA, Universidad Politécnica de Madrid)_an allergenic component not available in ImmunoCAP — was determined by direct ELISA as previously reported [17] in peanut-allergic patients with negative sIgE to peanut components in ISAC. The test was performed using patient sera at the corresponding dilution and rabbit anti-IgE antibody (dilution 1:5000; Biosource). Proteins were coated at $5 \mu \mathrm{g} / \mathrm{mL}$ in PBS blocking solution $(0.1 \%)$ (commercial digested casein SIGMA) without a solid

Table. Clinical and Demographic Characteristics of Patients and Controls

\begin{tabular}{|c|c|c|c|c|c|}
\hline & $\begin{array}{l}\text { Peanut-Allergic } \\
\text { Patients }\end{array}$ & $\begin{array}{l}\text { Hazelnut-Allergic } \\
\text { Patients }\end{array}$ & $\begin{array}{l}\text { Walnut-Allergic } \\
\text { Patients }\end{array}$ & $\begin{array}{l}\text { Nonatopic } \\
\text { Controls }\end{array}$ & $\begin{array}{l}\text { Atopic } \\
\text { Controls }\end{array}$ \\
\hline Individuals, No. & 39 & 36 & 44 & 44 & 37 \\
\hline Age, mean (SD), y & $29.7(9.1)$ & $29.6(8.7)$ & $31.1(9.5)$ & $47.3(15.2)$ & $39.6(14.2)$ \\
\hline Male sex, $\%$ & 28.2 & 27.7 & 36.4 & 25 & 37.8 \\
\hline \multicolumn{6}{|l|}{$\begin{array}{l}\text { Symptoms caused by } \\
\text { triggering nut, No. (\%) }\end{array}$} \\
\hline $\begin{array}{l}\text { Oral allergy syndrome } \\
\text { Systemic symptoms } \\
\text { Anaphylaxis }\end{array}$ & $\begin{array}{l}13(33.3) \\
16(41) \\
10(25.6)\end{array}$ & $\begin{array}{l}13(36.1) \\
13(36.1) \\
10(27.7)\end{array}$ & $\begin{array}{l}17(38.6) \\
16(36.4) \\
11(25)\end{array}$ & 0 & 0 \\
\hline $\begin{array}{l}\text { sIgE against nut, median } \\
\left(25-75 \text { percentile), } \mathrm{kU}_{\mathrm{A}} / \mathrm{L}\right.\end{array}$ & $1.31(0.75-5.9)$ & $1.96(1.03-7.18)$ & $1.73(1-4.81)$ & ND & ND \\
\hline $\begin{array}{l}\text { Positive Pru p } 3 \text { enriched peach } \\
\text { extract SPT, No. }(\%)\end{array}$ & $33(84.6)$ & $32(88.9)$ & $38(86.4)$ & 0 & 0 \\
\hline
\end{tabular}

Abbreviations: ND, not determined; slgE, specific lgE; SPT, skin prick test. 
phase. Bovine serum albumin as a solid phase or a serum pool from healthy individuals was used as a negative control in the different studies and optical density (OD) values greater than mean $[\mathrm{OD}]+3 \mathrm{x}$ SD with respect to the negative control were considered positive. Serum dilution was determined by tritration curves.

\section{Statistical Analysis}

Quantitative variables were described as means (SD) or as medians and interquartile ranges (25-75 percentile) when data distribution was not normal. Normality was assessed by the Shapiro-Wilk test. Qualitative variables were described as frequencies (percentages), and proportions were compared using the $\chi^{2}$ test. All statistical analyses were performed using Stata/IC 12.0. Differences were considered statistically significant when the $P$ value was less than .05 .

\section{Results}

\section{Nut-Allergic Patients}

We enrolled 66 patients with IgE-mediated allergic symptoms to peanut $(n=39)$, hazelnut $(n=36)$, or walnut $(n=44)$ with a positive SPT and SIgE to the corresponding tree nut(s). Eighteen patients were allergic to the 3 nuts, and 46 (69.7\%) were also allergic to peach. The demographic and clinical data for the patients and the 37 atopic and 44 nonatopic controls are summarized in the Table.

\section{Protein Microarray Sensitization Profile of Nut-Allergic Patients}

The ISAC microarray results showed that $66.6 \%$ of peanut-allergic patients, $80.5 \%$ of hazelnut-allergic patients,

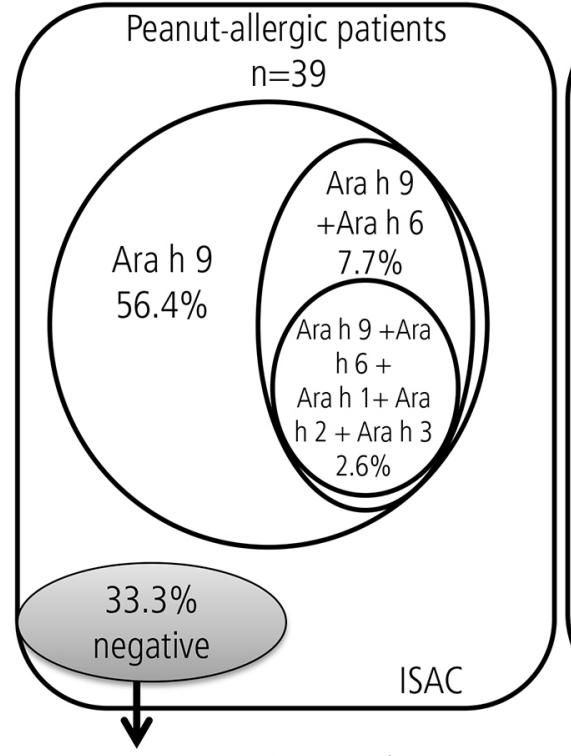

ISAC-negative peanut-allergic patients $(n=13)$

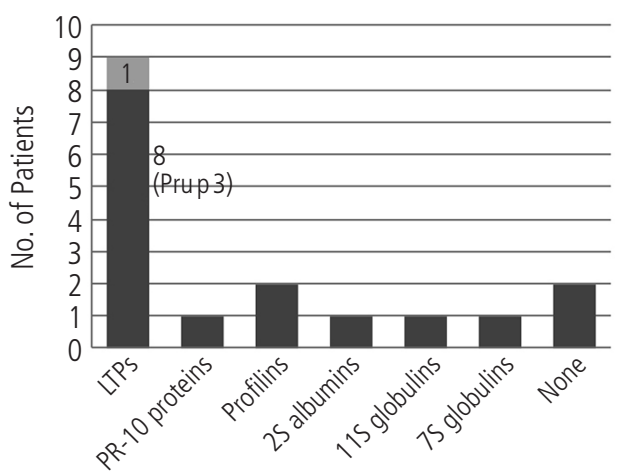

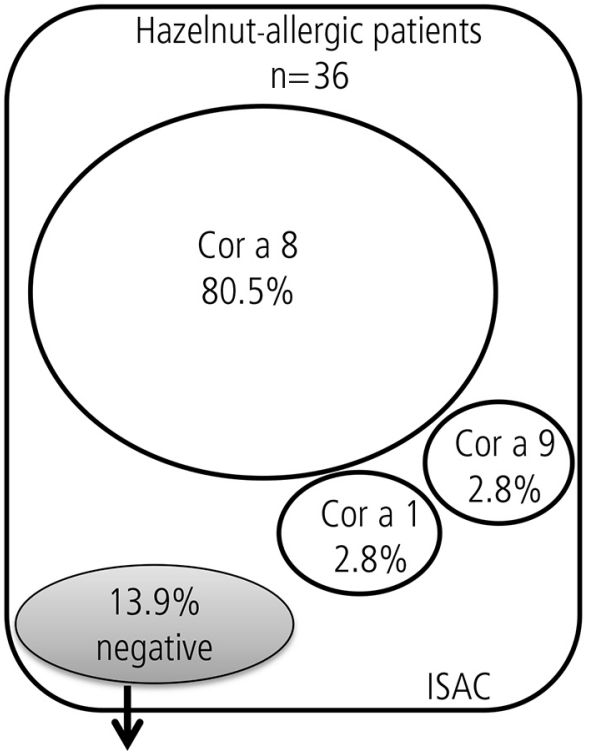

ISAC-negative hazelnut-allergic patients $(n=5)$

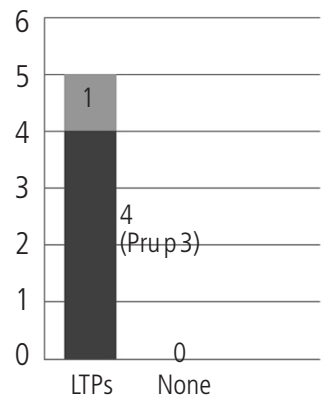

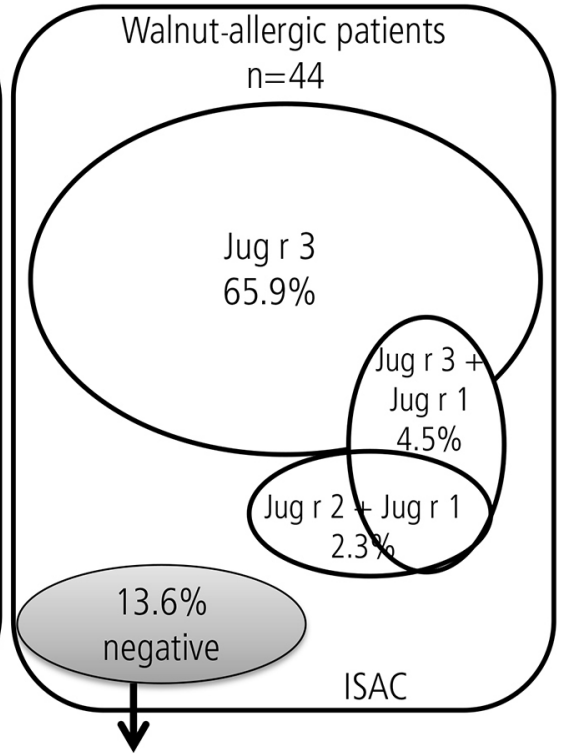

ISAC-negative walnut-allergic patients $(n=6)$

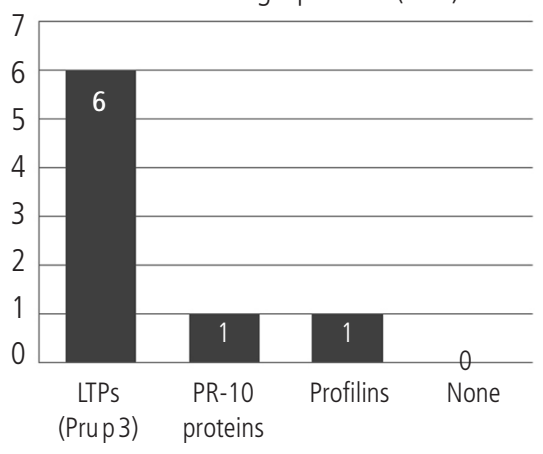

Figure 1. Sensitization profile of nut-allergic patients according to ImmunoCAP ISAC CRD112. Upper panel, summary of ISAC data regarding sensitization to nut allergens. Lower panel, summary of ISAC data regarding sensitization to panallergens and allergen families different from nuts. The number of patients sensitized to Pru $\mathrm{p} 3$ is shown in dark gray. LTP indicates lipid transfer protein. 


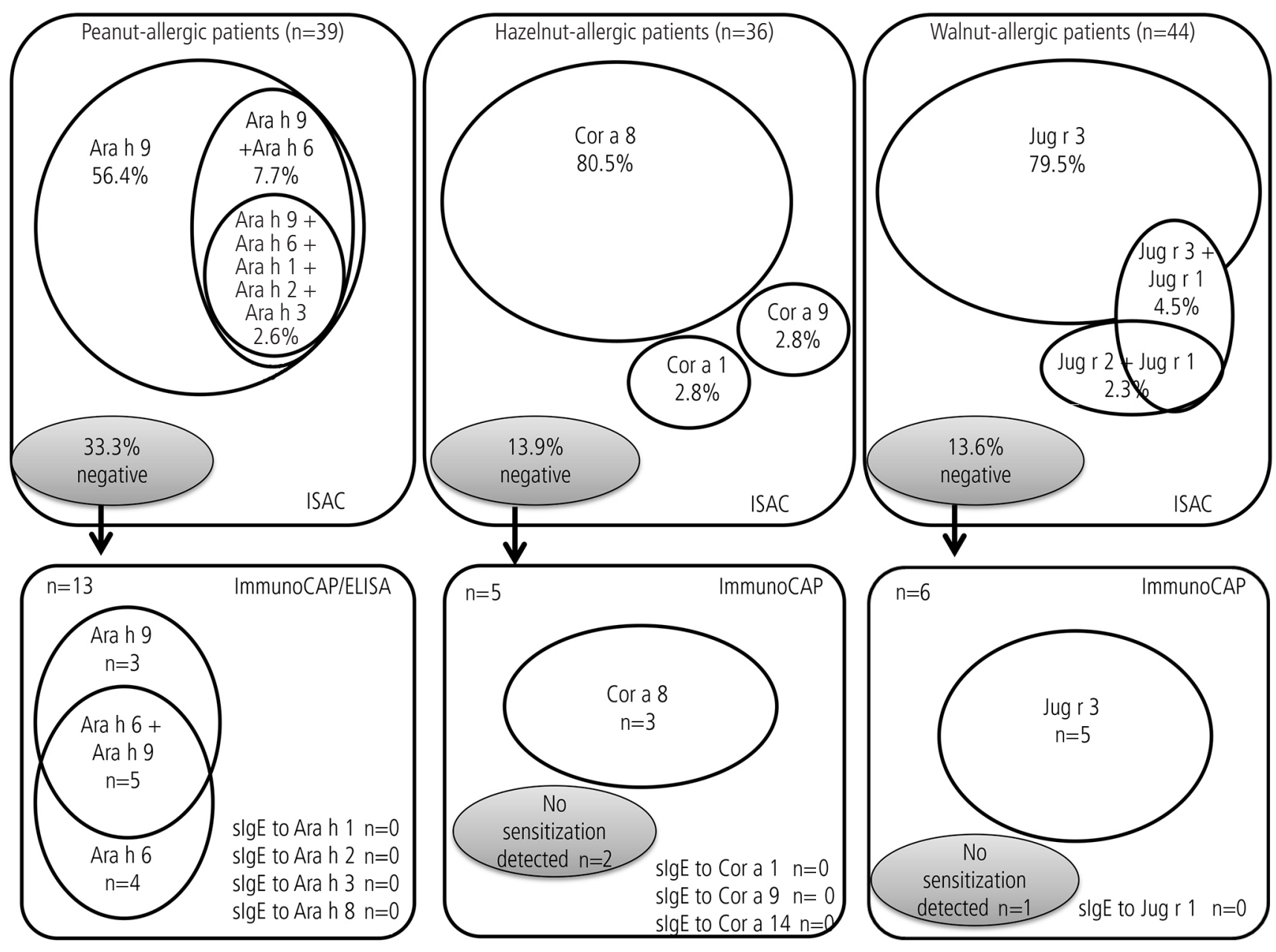

Figure 2. Sensitization profile of nut-allergic patients according to ImmunoCAP. Upper panel, summary of ISAC data regarding sensitization to nut allergens. Lower panel, summary of ImmunoCAP data regarding sensitization to nut components in nut-allergic patients with negative results to nut components in ISAC. slgE indicates specific lgE.

and $70.4 \%$ of walnut-allergic patients were sensitized to the corresponding LTP (Ara h9, Cor a 8, and Jugr 3, respectively) and that a small proportion of patients were also sensitized to other allergens. One third of peanut-allergic patients $(n=13)$, $13.9 \%$ of hazelnut-allergic patients $(n=5)$, and $13.6 \%$ of walnut-allergic patients $(n=6)$ did not show sIgE against any of nut components in ISAC. Figure 1 summarizes the sensitization profiles of nut-allergic patients according to the protein microarray results. None of the controls were sensitized to peanut components; 1 was sensitized to Cor a 8, 1 to Jugr 2, and 2 to Jugr 3 .

\section{Other Sensitizations in Nut-Allergic Patients With Negative ISAC Results}

Panallergen sensitization (profilin, PR-10 proteins, 2s albumin, $11 \mathrm{~s}$ globulin, and $7 \mathrm{~s}$ globulin) was assessed in nutallergic patients with negative results to the nut components in ISAC.

Sensitization to LTPs was common among nut-allergic patients without detectable sensitization to the triggering nut in ISAC. This sensitization was detected in 9 of the 13 patients with peanut allergy, in 5 of the 5 patients with hazelnut allergy, and in 6 of the 6 patients with walnut allergy. Most of the patients were sensitized to Prup 3 , and only a few were sensitized to PR-10 proteins (1/13 peanut-allergic and 1/6 walnut-allergic patients), profilins (2/13 peanut-allergic and $1 / 6$ walnut-allergic patients), or storage proteins ( $1 / 13$ peanutallergic patients to $2 \mathrm{~s}$ albumin, $1 / 13$ peanut-allergic patients to $11 \mathrm{~s}$ globulins, and 1/13 peanut-allergic patients to $7 \mathrm{~s}$ globulin). Only 2 peanut-allergic patients showed no sensitization to peanut components or panallergens/storage proteins by ISAC. These results are summarized in Figure 1.

\section{Sensitization as Assessed by Alternative Techniques in ISAC-Negative Nut-Allergic Patients}

sIgE against Ara h 1, Ara h 2, Ara h 3, Ara h 8 and Ara h 9 using ImmunoCAP and Ara h 6 using ELISA was measured in the 13 peanut-allergic patients in whom peanut sensitization was not detected by ISAC. ImmunoCAP showed SIgE against Arah 9 in 8 of these patients. Of these 8 patients, 5 were also 


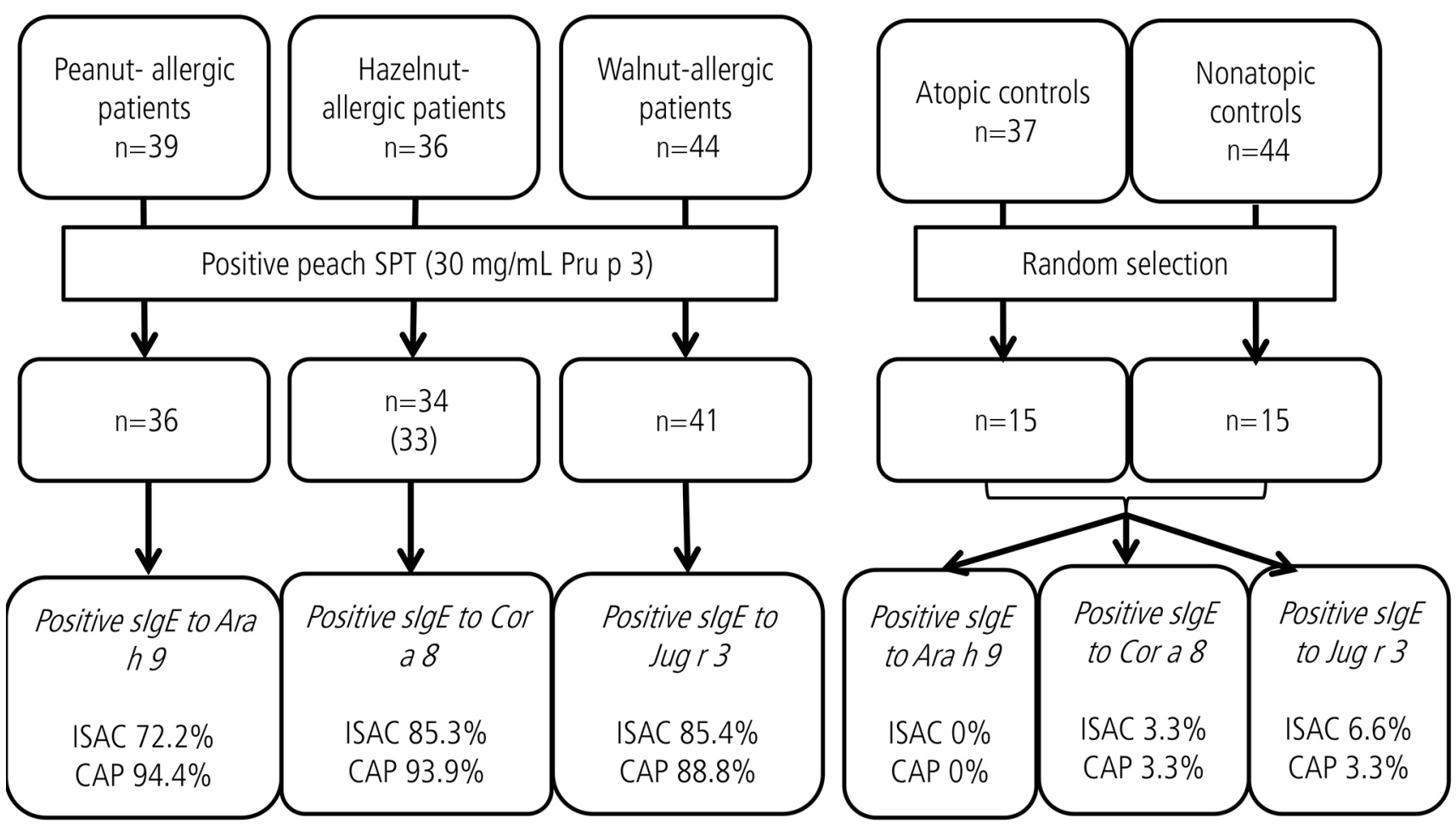

Figure 3. Specific IgE against nut LTPs according to CAP and ISAC in peach-sensitized peanut-, hazelnut-, walnut-allergic patients. Patients with serum available for ImmunoCAP determination are shown in brackets. SPT indicates skin prick test; slge, specific IgE.

sensitized to Ara h 6 according to ELISA. Four of the 13 patients were only sensitized to Ara $\mathrm{h} 6$ according to alternative techniques. No sensitization was detected to Ara h 1, Ara h 2, Ara $h 3$, or Ara $h 8$ by ImmunoCAP in any of the ISAC-negative peanut-allergic patients.

SIgE against Cor a 1, Cor a 8, Cor a 9, and Cor a 14 was determined by ImmunoCAP in the 5 hazelnut-allergic patients in whom hazelnut sensitization was not detected by ISAC. Three patients were found to be sensitized to Cor a 8 . No sensitization was detected for Cor a 1 , Cor a 9 , or Cor a 14 by CAP in any of the 5 ISAC-negative hazelnut-allergic patients.

sIgE against Jug r 1 and Jug r 3 was measured by ImmunoCAP in the 6 walnut-allergic patients in whom no walnut sensitization was detected by ISAC. ImmunoCAP showed 5 of the patients to be sensitized to Jug $r 3$ and none of the patients to be sensitized to Jug r 1. These data are summarized in Figure 2.

\section{Diagnostic Performance of the ISAC Microarray for Nut LTPS}

In order to assess the diagnostic performance of peanut, hazelnut, and walnut LTPs in ISAC, LTP-sensitized nutallergic patients were selected from our sample together with 30 controls (15 nonatopic controls and 15 atopic dust mite-allergic patients without plant allergen sensitization) randomly selected from the control group. LTP sensitization was defined as a positive SPT to Prup 3 enriched peach. Serum sIgE against peanut, hazelnut, and walnut LTPs was measured by ImmunoCAP. The flow chart of this subgroup is presented in Figure 3. sIgE against Ara h 9, Cor a 8, and Jug r 3 using ImmunoCAP and the ISAC microarray was measured in all patients and controls and then compared.

Serum sIgE against Ara 9 was detected in more peanutallergic peach-sensitized patients by ImmunoCAP $(94.4 \%$, $34 / 36)$ than by ISAC $(72.2 \%, 26 / 36)$ (2-tailed $P=.011)$. However, sIgE to Cora 8 and to Jugr 3 was detected to a similar degree by both techniques in hazelnut-allergic peach-sensitized patients (ISAC 85.3\% [29/34] vs ImmunoCAP 93.9\% [31/33], 2-tailed $P=.247$ ) and walnut-allergic peach-sensitized patients (ISAC 85.4\% [35/41] vs ImmunoCAP 87.8\% [36/41], $P=.746]$ ) Few controls showed sIgE against Ara 9 ( $0 / 30$ by ISAC and by ImmunoCAP), Cora 8 (1/30 by ISAC and by ImmunoCAP), or Jug 3 (2/30 by ISAC and $1 / 30$ by ImmunoCAP).

Specific IgE against nut LTPs using ImmunoCAP was compared with sIgE ranges obtained using ISAC. The data are shown in Figure 4.

\section{Discussion}

We confirmed in a well-defined group of patients allergic to peanut, hazelnut, and walnut that LTP is the main allergen in nut allergy, as has been previously reported in the Mediterranean area $[6-8,10]$. It is important to highlight that this study did not include children. This exclusion criterion may explain why only a few of the individuals analyzed were sensitized to common major allergens (storage proteins), since sensitization profiles have been reported to differ according to age [18-20]. The differential profile we observed 

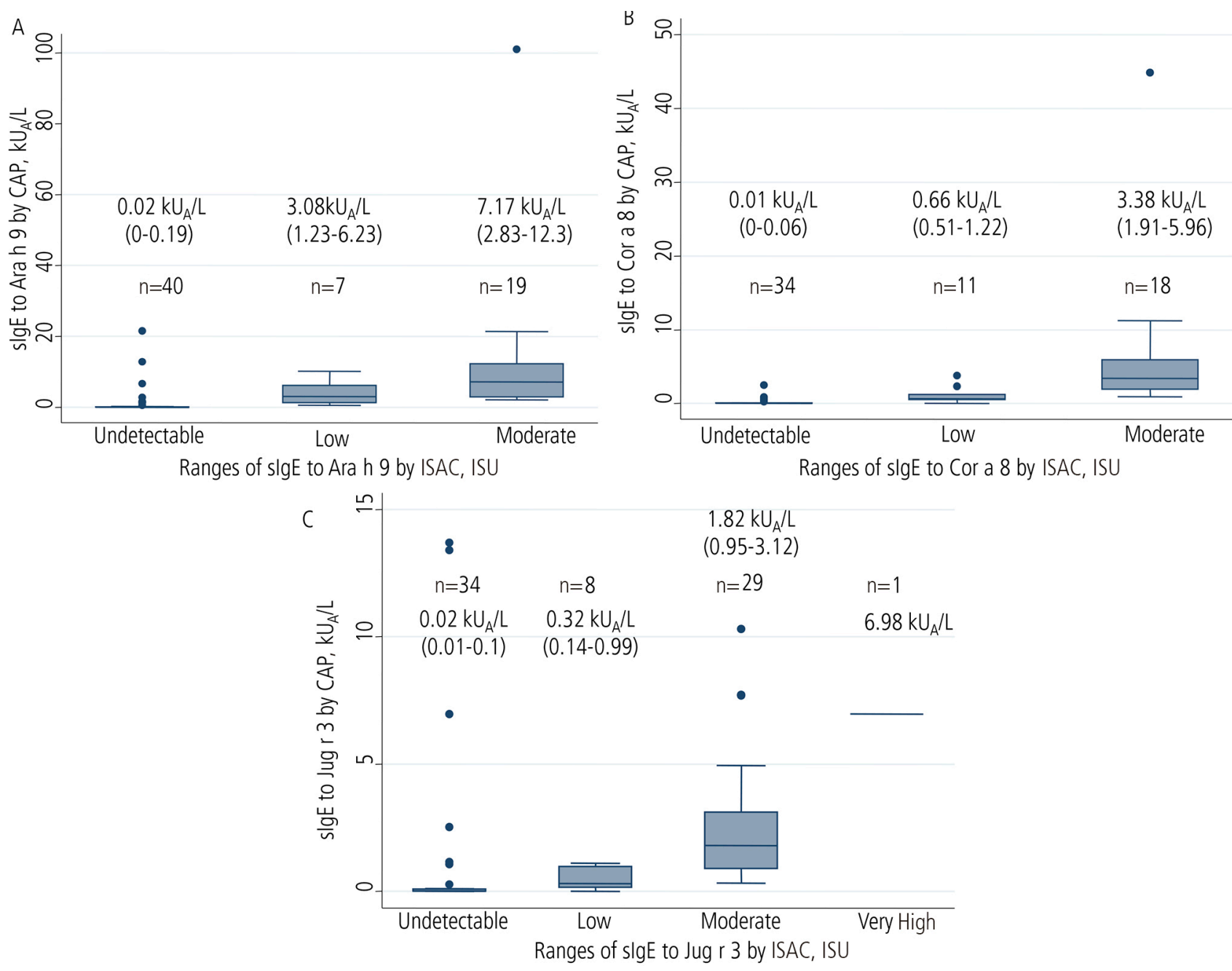

Figure 4. Specific IgE (slgE) against nut lipid transfer proteins by CAP regarding ISAC slgE ranges in peach-LTP-sensitized peanut-, hazelnut-, walnut-allergic patients.

with regard to other series may also have been influenced by geographic location $[6,20]$.

We also observed that not all nut-allergic patients were diagnosed by the ISAC protein microarray, since $33.3 \%$ of peanut-allergic patients (13/39), 13.9\% of hazelnut-allergic patients (5/36), and $13.6 \%$ walnut-allergic patients (6/44) did not show any SIgE against proteins from the nut responsible for their symptoms. Interestingly, Ara h 9 sensitization was detected by the consolidated ImmunoCAP in 8 of the 13 peanut-allergic patients with ISAC-negative results, suggesting that ISAC performs poorly in the detection of peanut LTP sensitization.

To assess the diagnostic performance of ISAC for the detection of sIgE to peanut, hazelnut, and walnut LTPs, we selected a subgroup of LTP-sensitized nut-allergic patients and controls. Based on the sIgE results from ImmunoCAP and ISAC against Ara h 9, Cor a 8, and Jug r 3 in this sample we can conclude that the sensitivity of the peanut LTP Ara h 9 needs to be improved in the ISAC platform, since ImmunoCAP outperformed ISAC in diagnosing cases of sensitization to Ara h 9 in peanut-allergic patients. Furthermore, this low diagnostic capacity in ISAC cannot be explained by low levels of sIgE, since according to ISAC, considerable SIgE values as determined by ImmunoCAP (including values $>20 \mathrm{kU}_{\mathrm{A}} / \mathrm{L}$ for Ara h 9) were recorded as undetectable (Figure 4A). Moreover, these discrepancies in sIgE values between ISAC and ImmunoCAP were also observed for Cor a 8 (Figure 4B) and Jug r 3 (Figure 4C). In the case of Jug r 3, the recombinant form is used in ImmunoCAP, while the natural form is used in ISAC. However, in the case of Ara h 9 and Cor a 8, according to the manufacturer's information, the recombinant forms of both these proteins are used in both tests. These data suggest that Ara $\mathrm{h} 9$ and Cor a 8 underwent a different folding process in the ISAC slide than in the ImmunoCAP polymer and this may have affected IgE binding.

Because Pru p 3 shows high cross-reactivity with Ara h 9 [21] and Jug r 3 [9], in addition to significant crossreactivity with Cor a 8 [22], in the Mediterranean area, the inclusion of this LTP in nut CRD diagnosis by ISAC helps to detect otherwise ISAC-negative patients. In fact, in ISAC, positive sIgE against specific nut components in addition to Pru p 3 diagnosed $87.2 \%$ (34/39) of all peanut-allergic 
patients, 97.2\% (35/36) of all hazelnut-allergic patients, and $100 \%(44 / 44)$ of all walnut-allergic patients compared with positive sIgE against specific nut components only (peanut, 26/36 [72.2\%], hazelnut, 31/36 [86.1\%], walnut, 38/44 $[86.4 \%]$ ). Although it has been suggested that a limited set of well-validated sensitization markers rather than a panel of components for CRD can facilitate allergy diagnosis [23], Pru $\mathrm{p} 3$ sensitization does not determine clinical reactivity to nuts as has been previously reported [10]. In conclusion, after confirming that LTP is the main allergen in peanut-, hazelnut-, and walnut-allergic patients in our area, we demonstrated that the sensitivity of the ISAC protein microarray can vary between certain allergens. In particular, the sensitivity of certain LTPs, such as the peanut LTP Arah 9, needs to be improved in ISAC.

\section{Acknowledgments}

We thank Mr Paul Miller for his invaluable help in reviewing the language of the manuscript and Maria Angeles Salgado and Sonia Ariz for their wonderful technical work.

\section{Funding}

This research was financially supported by Instituto de Salud Carlos III (Grant: PI 11/01634) and by grant RD12/0013/00010 from the Spanish Research Network on Adverse Reactions to Allergens and Drugs (RIRAAF: Red de Investigación de Reacciones Adversas a Alérgenos y Fármacos) of the Carlos III Health Institute.

\section{Conflicts of Interest}

The authors declare that they have no conflict of interest.

\section{References}

1. Nwaru BI, Hickstein L, Panesar SS, Muraro A, Werfel T, Cardona $V$, Dubois AEJ, Halken S, Hoffmann-Sommergruber $K$, Poulsen LK, Roberts G, Van Ree R, Vlieg-Boerstra BJ, Sheikh A, the EFA, Anaphylaxis Guidelines $G$. The epidemiology of food allergy in Europe: a systematic review and meta-analysis. Allergy. 2014;69(1):62-75.

2. Asero R, Antonicelli L, Arena A, Bommarito L, Caruso B, Colombo G, Crivellaro M, De Carli M, Della Torre E, Della Torre F, Heffler E, Lodi Rizzini F, Longo R, Manzotti G, Marcotulli M, Melchiorre A, Minale P, Morandi P, Moreni B, Moschella A, Murzilli F, Nebiolo F, Poppa M, Randazzo S, Rossi G, Senna GE. Causes of food-induced anaphylaxis in Italian adults: a multicentre study. Int Arch Allergy Immunol. 2009;150:271-77.

3. Gamboa PM, Caceres O, Antepara I, Sanchez-Monge R, Ahrazem O, Salcedo G, Barber D, Lombardero M, Sanz ML. Two different profiles of peach allergy in the north of Spain. Allergy. 2007;62:408-14.

4. Fernandez-Rivas M, Bolhaar S, Gonzalez-Mancebo E, Asero $R$, van Leeuwen $A$, Bohle $B$, Ma Y, Ebner $C$, Rigby $N$, Sancho Al, Miles S, Zuidmeer L, Knulst A, Breiteneder $H$, Mills C, Hoffmann-Sommergruber K, van Ree R. Apple allergy across Europe: how allergen sensitization profiles determine the clinical expression of allergies to plant foods. J Allergy Clin Immunol. 2006;118:481-8.
5. Fernandez-Rivas $M$, Gonzalez-Mancebo $E$, Rodriguez-Perez $R$, Benito C, Sanchez-Monge R, Salcedo G, Alonso MD, Rosado A, Tejedor MA, Vila C, Casas ML. Clinically relevant peach allergy is related to peach lipid transfer protein, Pru p 3, in the Spanish population. J Allergy Clin Immunol. 2003;112:789-95.

6. Hansen KS, Ballmer-Weber BK, Sastre J, Lidholm J, Andersson K, Oberhofer $H$, Lluch-Bernal M, Ostling J, Mattsson L, Schocker F, Vieths S, Poulsen LK. Component-resolved in vitro diagnosis of hazelnut allergy in Europe. J Allergy Clin Immunol. 2009;123:1134-41.

7. Vereda $A$, van Hage $M$, Ahlstedt $S$, Ibanez MD, CuestaHerranz J, van Odijk J, Wickman M, Sampson HA. Peanut allergy: Clinical and immunologic differences among patients from 3 different geographic regions. J Allergy Clin Immunol. 2011;127:603-7.

8. Javaloyes G, Goikoetxea MJ, Garcia Nunez I, Aranda A, Sanz ML, Blanca M, Diaz Perales A, da Souza J, Esparza I, del Pozo $V$, Blazquez AB, Scheurer S, Vieths S, Ferrer M. Pru p 3 acts as a strong sensitizer for peanut allergy in Spain. J Allergy Clin Immunol. 2012;130:1432-4.

9. Pastorello EA, Farioli L, Pravettoni $V$, Robino AM, Scibilia J, Fortunato D, Conti A, Borgonovo L, Bengtsson A, Ortolani C. Lipid transfer protein and vicilin are important walnut allergens in patients not allergic to pollen. J Allergy Clin Immunol. 2004;114:908-14.

10. Krause S, Reese G, Randow S, Zennaro D, Quaratino D, Palazzo P, Ciardiello MA, Petersen A, Becker WM, Mari A. Lipid transfer protein (Ara h 9) as a new peanut allergen relevant for a Mediterranean allergic population. J Allergy Clin Immunol. 2009;124:771-8.

11. Canonica G, Ansotegui I, Pawankar R, Schmid-Grendelmeier $P$, van Hage $M$, Baena-Cagnani C, Melioli G, Nunes C, Passalacqua G, Rosenwasser L, Sampson H, Sastre J, Bousquet J, Zuberbier T, WAO-ARIA-GA2LEN Task Force. A WAO - ARIA - GA^2LEN consensus document on molecular-based allergy diagnostics. World Allergy Organization Journal. 2013;6:17.

12. Ebo DG, Bridts $C H$, Verweij MM, De Knop KJ, Hagendorens MM, De Clerck LS, Stevens WJ. Sensitization profiles in birch pollen-allergic patients with and without oral allergy syndrome to apple: lessons from multiplexed componentresolved allergy diagnosis. Clin Exp Allergy. 2010;40:339-47.

13. Klemans RJB, Liu X, Knulst AC, Knol MJ, Gmelig-Meyling F, Borst E, Pasmans SGMA, Knol EF. IgE binding to peanut components by four different techniques: Ara $h 2$ is the most relevant in peanut allergic children and adults. Clin Exp Allergy. 2013;43:967-74.

14. Javaloyes G, Goikoetxea MJ, Garcia Nunez I, Sanz ML, Blanca M, Scheurer S, Vieths S, Ferrer M. Performance of different in vitro techniques in the molecular diagnosis of peanut allergy. J Investig Allergol Clin Immunol. 2012;22:508-13.

15. Villalta D, Conte M, Asero R, Da Re M, Stella S, Martelli P. Isolated IgE reactivity to native walnut vicilin-like protein (nJug $r$ 2) on ISACTM microarray is due to cross-reactive carbohydrate epitopes. Clin Chem Lab Med. 2013:1991.

16. Position paper: Allergen standardization and skin tests. The European Academy of Allergology and Clinical Immunology. Allergy. 1993;48(14 Suppl):48-82.

17. Diaz-Perales $A$, Lombardero $M$, Sanchez-Monge $R$, GarciaSelles FJ, Pernas M, Fernandez-Rivas M, Barber D, Salcedo G. 
Lipid-transfer proteins as potential plant panallergens: crossreactivity among proteins of Artemisia pollen, Castanea nut and Rosaceae fruits, with different IgE-binding capacities. Clin Exp Allergy. 2000;30:1403-10.

18. Masthoff LJN, Mattsson L, Zuidmeer-Jongejan L, Lidholm J, Andersson K, Akkerdaas JH, Versteeg SA, Garino C, Meijer Y, Kentie $P$, Versluis A, den Hartog Jager CF, Bruijnzeel-Koomen CAFM, Knulst AC, van Ree $R$, van Hoffen $E$, Pasmans SGMA. Sensitization to Cor a 9 and Cor a 14 is highly specific for a hazelnut allergy with objective symptoms in Dutch children and adults. J Allergy Clin Immunol. 2013;132:393-9.

19. Faber MA, De Graag $M$, Van Der Heijden C, Sabato $V$, Hagendorens MM, Bridts CH, De Clerck LS, Ebo DG. Cor a 14: Missing link in the molecular diagnosis of hazelnut allergy? Int Arch Allergy Immunol 2014;164:200-6.

20. Ballmer-Weber BK, Lidholm J, Fernández-Rivas $M$, Seneviratne S, Hanschmann K-M, Vogel L, Bures P, Fritsche P, Summers C, Knulst AC, Le T-M, Reig I, Papadopoulos NG, Sinaniotis A, Belohlavkova S, Popov T, Kralimarkova T, de Blay F, Purohit A, Clausen M, Kowalski ML, Asero R, Dubakiene R, Barreales L, Clare Mills EN, van Ree $R$, Vieths $S$. IgE recognition patterns in peanut allergy are age dependent: perspectives of the EuroPrevall study. Allergy. 2015;70:391-407.

21. Lauer I, Dueringer N, Pokoj S, Rehm S, Zoccatelli G, Reese G, Miguel-Moncin MS, Cistero-Bahima A, Enrique E, Lidholm J,
Vieths $S$, Scheurer $S$. The non-specific lipid transfer protein, Ara $\mathrm{h}$ 9, is an important allergen in peanut. Clin Exp Allergy. 2009;39:1427-37.

22. Hartz C, Lauer I, del Mar San Miguel Moncin M, Cistero-Bahima A, Foetisch K, Lidholm J, Vieths S, Scheurer S. Comparison of IgE-binding capacity, cross-reactivity and biological potency of allergenic non-specific lipid transfer proteins from peach, cherry and hazelnut. Int Arch Allergy Immunol. 2010;153:33546.

23. Salcedo G, Diaz-Perales A. Component-resolved diagnosis of allergy: more is better? Clin Exp Allergy. 2010;40:836-8.

Manuscript received July 29, 2015; accepted for
publication, August 24, 2015.

- María José Goikoetxea

Department of Allergy

Clinica Universidad de Navarra

Pio XII,36. 31008

Pamplona, Spain

E-mail: mjgoiko@unav.es 